\title{
Role of active and passive smoking on lung cancer etiology in Mexico City
}

Francisco Franco-Marina MC, MPH, MHSc, (1) Jaime Villalba Caloca, MC, M en C, ${ }^{(2)}$ Alexander Corcho-Berdugo, MC, ${ }^{(2)}$ Grupo interinstitucional de cáncer pulmonar*

\section{Franco-Marina F, Villalba-Caloca J, Corcho-Berdugo A, Grupo interinstitucional de cáncer pulmonar. Role of active and passive smoking on lung cancer etiology in Mexico City. Salud Publica Mex 2006;48 suppl I:S75-S82.}

\begin{abstract}
Objective. To estimate the association between passive and active smoking exposures and lung cancer in Mexico City and the corresponding attributable risks. Material and Methods. Data was analyzed from a multicenter population-based case-control study conducted in Mexico City. Results. ORs for lung cancer in ever smokers were 6.2 $(95 \% \mathrm{Cl} 3.9-10.2)$ for males and $2.8(95 \% \mathrm{Cl}$ l.7-4.4) for females. Passive smoking at home showed an overall OR of I.8 (95\% Cl I.3-2.6), similar in both genders. Attributable risk for active smoking for both genders combined, and for males and females separately, was estimated at 55, 76 and $27 \%$, respectively. Attributable risk for passive smoking at home was $17 \%$ for females, $3.9 \%$ for males and $12 \%$ for the entire population. Conclusions. In Mexico City smoking is attributable to a smaller proportion of lung cancer cases than in developed countries. This is explained by a lower intensity of smoking in the Mexican population.
\end{abstract}

Keywords: lung cancer, cigarette smoking, odds ratio, attributable risk, epidemiologic methods, case-control; Mexico

\author{
Franco-Marina F, Villalba-Caloca J, \\ Corcho-Berdugo A, \\ Grupo interinstitucional de cáncer pulmonar. \\ Papel del tabaquismo activo y pasivo en la \\ etiología del cáncer en la Ciudad de México. \\ Salud Publica Mex 2006;48 supl I:S75-S82
}

\section{Resumen}

Objetivo: Estimar la asociación entre tabaquismo pasivo y activo y cáncer pulmonar (CP) en la Ciudad de México (CM), así como los riesgos atribuibles asociados. Material y métodos: Se analiza un estudio multicéntrico de casoscontroles con base poblacional, realizado en la CM. Resultados: Las RM para CP en alguna vez fumadores fueron de 6.2 (IC 95\% 3.9, I0.2) en hombres y 2.8 (IC 95\% I.7,4.4) en mujeres. La exposición pasiva al tabaco mostró una RM en ambos sexos de I.8 (IC 95\% I.3, 2.6), similar en ambos sexos. Los riesgos atribuibles asociados al tabaquismo activo para ambos sexos, hombres y mujeres fueron de 55,76 y $27 \%$, respectivamente. El riesgo atribuible para tabaquismo fue de $17 \%$ en mujeres, $3.9 \%$ en hombres y $12 \%$ en ambos sexos. Conclusiones: En la CM el tabaquismo explica una fracción menor de casos de CP que el estimado en países desarrollados. Esto se debe a que en México la intensidad del tabaquismo es menor.

Palabras clave: cáncer pulmonar, tabaquismo, razón de momios, riesgo atribuible, métodos epidemiológicos, casos-control; México

Este estudio recibió financiamiento de la Fundación Mexicana para la Salud (FUNSALUD).

(I) Centro de Investigación en Salud Poblacional. Instituto Nacional de Salud Pública, México

(2) Unidad de Investigación. Instituto Nacional de Enfermedades Respiratorias, México

* Grupo interinstitucional de cáncer pulmonar: Dr. Carlos Ibarra Pérez, Hospital de Oncología, Centro Médico Nacional Siglo XXI, IMSS; Dr. Frumencio Medina Morales, Instituto Nacional de Enfermedades Respiratorias; Dr. Raúl Cicero Sabido y Dra. Ma. Ernestina Ramírez Casanova, Hospital General de México; Dr. Leon Green Schnweeiss y Dra. Elma Correa Acevedo, Instituto Nacional de Cancerología; Dr. Enrique Téllez Díaz, Centro Médico 20 de Noviembre, ISSSTE; Dr. Gerardo Rico Méndez y Dr. José Luís Espinoza Pérez, Hospital de Especialidades, Centro Médico La Raza, IMSS.

Fecha de recibido: 7 de marzo de 2006 - Fecha de aprobado: 21 de abril de 2006 Solicitud de sobretiros: Francisco Franco Marina. Centro de Investigación en Salud Poblacional, Instituto Nacional de Salud Pública. Av. Universidad 655, Col. Sta. María Ahuacatitlán, 62508 Cuernavaca, Morelos, México. Correo eléctrónico: franciscofranco@salud.gob.mx 
$\mathrm{T}^{\mathrm{o}}$ obacco smoking is a well known cause of lung cancer. A recent report estimates that, worldwide, tobacco smoking is responsible for $92 \%$ of all lung cancer deaths in males and $71 \%$ of all lung cancer deaths occurring in females. ${ }^{1}$ However, such figures are not necessarily applicable to specific countries. The proportion of lung cancer cases attributable to tobacco exposure depends basically on the magnitude of the association, measured by the odds ratio, as well as on the prevalence of smoking in a particular society. The odds ratio found in a given country depends, in turn, on the average intensity of smoking: the greater the intensity of the habit in a society, the larger the odds ratio relating smoking to lung cancer. Therefore, it was decided to estimate the fraction of lung cancer cases arising in Mexico City that could be attributed to smoking, considering both active and passive smoking. In this paper, preliminary data is used from a case control study on risk factors for lung cancer that was conducted among residents of the greater Mexico City area in order to estimate the risks of lung cancer attributable to tobacco in the city. This study was conducted with the aim of identifying indoor and outdoor pollutants that could be linked to lung cancer, but detailed information on smoking was also included in the questionnaire.

\section{Materials and Methods}

A population-based multicenter case-control study was conducted in the resident population of the greater Mexico City area, comprising 16 boroughs of the Federal District and 33 conurbation municipalities in the State of Mexico. Between January 2000 and April 2002, potential cases were actively ascertained in six public tertiary care hospitals located in the city ("Hospital de Oncología, Siglo XXI", "Hospital de Especialidades, La Raza", "Servicio de Neumología, Hospital General de México", "Centro Hospitalario 20 de Noviembre", "Instituto Nacional de Cancerología" and "Instituto Nacional de Enfermedades Respiratorias"). Potential cases were interviewed, either in the health care facilities or at their homes, as soon as they were identified, usually before diagnosis, if they complied with the following criteria: a) their age was 47 years or older, b) their address was located in the greater Mexico City area and c) they had started care for their current illness at the health care facility. Over the ascertainment period a total of 990 interviews were conducted of potential cases identified at the study hospitals. Details on diagnostic procedures, pathology results and signs and symptoms are in the process of being abstracted in a standardized manner from the medical records. To date, 665 medical records of potential cases from all the study hospitals have been reviewed. Of them, 385 correspond to both histologically and clinically confirmed primary lung cancer, 72 to metastatic lung tumors or other diseases and 208 to cases not yet classified as lung cancer. The analysis in this paper is restricted to the 385 confirmed lung cancer cases.

Controls were selected as follows: A multistage household probabilistic survey was carried out in early 1999 in the greater Mexico City area. Over 11000 households were visited and a structured questionnaire was administered to residents by trained interviewers. From this survey, 8393 persons were identified aged 47 years and older living in the selected households. They constitute the sampling frame from which the controls were randomly selected within strata by gender, access to health care through social security and 5-year age groups (except for the first age group which spanned from 47 to 50 years of age). The proportions of controls selected in each stratum were determined according to the proportions observed in potential cases interviewed of the same stratum when 500 interviews among them were completed, with the expectation of interviewing one control per case. Controls were interviewed in their households or at their workplace.

The same structured questionnaire was administered to both cases and controls by two trained interviewers who were not aware of the main study hypotheses. Interviewers were randomly assigned to administer interviews to cases on a weekly basis at specific hospitals included in the study. Controls for interviews were randomly assigned to the interviewers. The administered questionnaire contained questions on passive and active smoking exposure, biomass used for cooking, physical activity and detailed information on the addresses in which the interviewed persons have lived, gone to school and worked while residing in Mexico City.

Questionnaire data were entered twice and were analyzed using Stata version 8.0. Odds ratios (OR) and $95 \%$ confidence intervals (95\% CI) were obtained for smoking exposure variables through unconditional logistic regression models. Due to the use of frequency matching for control selection, all models included terms for age (continuous measurement) and access to social security. Models were fitted separately for each gender and also for both genders. Models for both genders also included a term for gender. Finally, a model including ever smoking and passive smoking at home was fitted, which also included terms for the frequency matching variables just described.

Using this last model and information on the prevalence of ever smokers and passive smokers at home in the control group, the population attributable risks 
(PARs) of lung cancer from these exposures were also estimated for each gender and for both combined. Because frequency matching was used to select the controls from the random sample of Mexico City residents drawn in the 1999 survey, the prevalence of these exposures in Mexico City was estimated by incorporating the inverse of the probability weight of selection of a control in each stratum with the matching variables. PARs were obtained through a Monte Carlo simulation, as described by Greenland. ${ }^{2}$ One thousand dataset replicates of the same size as the original dataset, with observations selected with replacement were generated for each gender and also for both genders. In each replication, an estimate was obtained of both the adjusted odds ratio and the weighted prevalence of ever smokers and passive smokers at home through the same methods described for the original data. With these data a PAR estimate was also obtained in each replication. Finally, by obtaining the mean and standard deviation of the complementary log transformation Lp $=(1-P A R)$ in the replications, the point estimate and corresponding 95\% $\mathrm{CI}$ for the PAR were obtained using the normal approximation formula presented by Greenland.

\section{Results}

Interviews were conducted in 898 controls which were compared in this paper to 385 lung cancer cases.

Compared to lung cancer cases, controls had a slightly greater proportion of females (Table I). Lung cancer cases tended to be older than controls and represented a greater proportion of persons with access to health care through social security. Cases also showed a higher proportion than controls of persons with 13 or more years of schooling and a lower proportion of illiterate persons.

Table II presents the effect, adjusted for the frequency matching variables and educational level, of several active and passive smoking variables on the odds of lung cancer, separately for each gender and for both genders. Male ever smokers increased their odds of developing lung cancer by a factor of six, whereas females increased their corresponding odds by a factor of almost three. This difference, in effect, was statistically significant. Current smokers had greater odds for disease than former and never smokers in both males and females, but again the effect of current and former smoking on the odds of developing lung cancer was significantly greater for males. A consistent upward trend towards higher relative odds was observed with regard to the number of cigarettes smoked per day in both genders. Odds ratios for this variable were in fact similar among males and females. The odds
TABLE I

SOCIODEMOGRAPHIC CHARACTERISTICS OF LUNG CANCER Cases and population controls in Mexico City

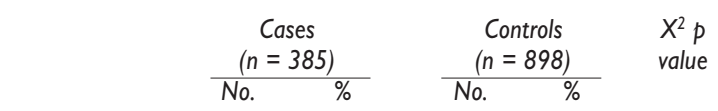

\begin{tabular}{lrrrrr}
$\begin{array}{l}\text { Gender } \\
\text { Male }\end{array}$ & 258 & 67.0 & 553 & 61.6 & \\
\hline Female & 127 & 33.0 & 345 & 38.4 & 0.064 \\
Age & & & & & \\
$47-49$ & 6 & 1.6 & 5 & 0.6 & \\
\hline $50-59$ & 101 & 26.2 & 277 & 30.8 & \\
\hline $60-69$ & 136 & 35.3 & 311 & 34.6 & \\
\hline $70-79$ & 109 & 28.3 & 200 & 22.3 & \\
\hline $80-102$ & 33 & 8.6 & 105 & 11.7 & 0.020
\end{tabular}

Access to health

care through

social security

\begin{tabular}{lrrrrr} 
Yes & 296 & 76.9 & 553 & 61.6 & \\
\hline No & 89 & 23.1 & 345 & 38.4 & $<0.001$
\end{tabular}

Educational level

(years of school)

\begin{tabular}{lrrrrr} 
Illiterate & 43 & 11.2 & 178 & 19.8 & \\
\hline $1-6$ & 206 & 53.5 & 474 & 52.8 & \\
\hline $7-9$ & 47 & 12.2 & 122 & 13.6 & \\
\hline $10-12$ & 42 & 10.9 & 66 & 7.3 & \\
\hline$\geq 13$ & 47 & 12.2 & 58 & 6.5 & $<0.001$
\end{tabular}

of developing lung cancer also increased as the duration of smoking increased and, in this case, the odds ratios were also similar between genders.

Cumulative smoking exposure, measured in packyears, also showed a consistent direct relationship with the odds of lung cancer, which was similar in both genders. Additionally, the odds of developing lung cancer were higher the younger the person started smoking and the effect of how young a person started smoking on the odds of developing the disease was greater in males. Being exposed to other persons smoking at home increased the odds of developing lung cancer by a factor of 1.8 in males and 1.7 in females.

The effect of quitting smoking is shown in Table III. A never quitter would have reduced their risk of developing lung cancer by $79 \%$ if they had never smoked. If a male never smoker were to give up his habit before he reaches 35 years of age he would reduce his risk by $68 \%$, and a woman in the same situation would have reduced her risk by $57 \%$. These data suggest that quitting smoking at even older ages still carries an important reduction in risk, although the sample size does not have sufficient power to estimate such reduction for persons who have quit smoking at 


\section{TABLE II}

\section{Odds RATIOS ${ }^{\dagger}$ FOR LUNG CANCER FROM ACTIVE AND PASSIVE SMOKING EXPOSURE VARIABLES in MeXico City, ACcording to gender}

\begin{tabular}{|c|c|c|c|c|c|c|c|c|c|}
\hline \multirow{2}{*}{ Smoking exposure variable } & \multicolumn{3}{|c|}{ Males } & \multicolumn{3}{|c|}{ Females } & \multicolumn{3}{|c|}{ Both genders } \\
\hline & Cases/Controls & $O R$ & $95 \% \mathrm{Cl}$ & Cases/Controls & OR & $95 \% \mathrm{Cl}$ & Cases/Controls & $O R$ & $95 \% \mathrm{Cl}$ \\
\hline \multicolumn{10}{|l|}{ Ever Smoker $\S$} \\
\hline No & $22 / 197$ & I & & $72 / 274$ & I & & $94 / 47 \mid$ & I & \\
\hline Yes & $236 / 356$ & 6.3 & $3.9,10.2$ & $55 / 71$ & 2.8 & $1.7,4.4$ & $291 / 427$ & 4.0 & $2.9,5.5$ \\
\hline \multicolumn{10}{|l|}{ Smoking status $\$$} \\
\hline Never smoker & $22 / 197$ & I & & $72 / 274$ & I & & 94/47I & I & \\
\hline Ex-smoker & $99 /|8|$ & 5.0 & $3.0,8.4$ & $22 / 35$ & 2.1 & $1.1,3.9$ & $121 / 216$ & 3.2 & $2.2,4.5$ \\
\hline Current & $137 / 175$ & 7.8 & $4.7,13.0$ & $33 / 36$ & 3.5 & $2.0,6.2$ & $|70 / 2| \mid$ & 4.9 & $3.5,7.0$ \\
\hline \multicolumn{10}{|l|}{ No. of cigarettes/day ${ }^{\pi}$} \\
\hline Never smoker & $22 / 197$ & I & & $72 / 274$ & I & & $94 / 47 \mid$ & I & \\
\hline $0.2-1.9$ & $14 / 69$ & 2.0 & $0.9,4.1$ & $8 / 23$ & 1.3 & $0.6,3.2$ & $22 / 92$ & 1.5 & $0.9,2.6$ \\
\hline $2-3.9$ & $18 / 92$ & 1.8 & $0.9,3.6$ & $9 / 24$ & 1.3 & $0.6,3.0$ & $27 / 116$ & 1.4 & $0.9,2.4$ \\
\hline $4-9.9$ & $61 / 98$ & 5.7 & $3.3,9.9$ & $12 / 16$ & 2.8 & $1.2,6.4$ & $73 / 114$ & 4.4 & $2.9,6.6$ \\
\hline $10-14.9$ & $47 / 55$ & 7.6 & $4.2,13.9$ & $13 / 5$ & 11.7 & $3.8,35.6$ & $60 / 60$ & 6.9 & $4.3,11.0$ \\
\hline $15-19.9$ & $47 / 24$ & 19.1 & $9.7,37.5$ & $8 / 1$ & 23.1 & $2.8,194$ & $55 / 25$ & 16.2 & $9.1,28.8$ \\
\hline $20-60$ & $49 / 18$ & 25.1 & $|2.3,5| .2$ & $5 / 2$ & 10.1 & $1.8,56.5$ & $54 / 20$ & 19.3 & $10.5,35.6$ \\
\hline \multicolumn{10}{|l|}{ Duration of smoking, $\mathrm{yr} \pi$} \\
\hline Never smoker & $22 / 197$ & I & & $72 / 274$ & I & & $94 / 47 \mid$ & I & \\
\hline $1-29$ & $31 / 87$ & 3.4 & $1.9,6.3$ & $12 / 18$ & 2.0 & $0.9,4.5$ & $43 / 105$ & 2.4 & $1.5,3.7$ \\
\hline $30-39$ & $55 / 89$ & 5.4 & $3.0,9.5$ & $15 / 23$ & 2.3 & I.I, 4.8 & $70 / 112$ & 3.5 & $2.3,5.2$ \\
\hline $40-49$ & $73 / 101$ & 6.7 & $3.9,11.5$ & $9 / 16$ & 2.5 & $1.0,6.2$ & $82 / 117$ & 4.3 & $2.8,6.4$ \\
\hline $50-76$ & $77 / 79$ & 10.3 & $5.8,18.3$ & $19 / 14$ & 4.9 & $2.2,10.6$ & $96 / 93$ & 6.6 & $4.4,10.1$ \\
\hline \multicolumn{10}{|c|}{$\begin{array}{l}\text { Lifetime cigarette consumption, } \\
\text { Pack, } y r^{\Uparrow}\end{array}$} \\
\hline Never smoker & $22 / 197$ & I & & $72 / 274$ & I & & $94 / 47 \mid$ & I & \\
\hline $0.01-2.9$ & $16 / 83$ & 1.8 & $0.9,3.7$ & $9 / 24$ & 1.3 & $0.6,3.0$ & $25 / 107$ & 1.5 & $0.9,2.5$ \\
\hline $3.0-7.9$ & $24 / 79$ & 2.8 & $1.4,5.3$ & $10 / 29$ & 1.4 & $0.6,3.0$ & $34 / 108$ & 1.9 & $|.2,3|$. \\
\hline $8.0-18.9$ & $51 / 94$ & 5.0 & $2.9,8.9$ & $11 / 10$ & 3.8 & $1.5,9.6$ & $62 / 104$ & 4.2 & $2.7,6.5$ \\
\hline $19.0-29.9$ & $37 / 55$ & 6.3 & $3.4,11.7$ & $9 / 5$ & 6.4 & $2,20.9$ & $46 / 60$ & 5.4 & $3.3,8.8$ \\
\hline $30.0-49.9$ & $64 / 36$ & 16.0 & $8.7,29.5$ & $11 / 3$ & 14.9 & $3.9,57.8$ & $75 / 39$ & 13.6 & $8.2,22.4$ \\
\hline $50.0-156.8$ & $44 / 9$ & 49.4 & $20.7,117.6$ & $5 / 0$ & $\infty$ & & $49 / 9$ & 41.8 & $18.9,92.4$ \\
\hline \multicolumn{10}{|l|}{ Age started smoking, $y r^{\S \pi}$} \\
\hline Never smoker & $22 / 197$ & I & & $72 / 274$ & I & & $94 / 47 \mid$ & I & \\
\hline $20-65$ & $58 / 106$ & 5.2 & $3.0,9.1$ & $32 / 40$ & 2.9 & $1.7,5.2$ & $90 / 146$ & 3.4 & $2.4,5.0$ \\
\hline $15-19$ & $98 / 156$ & 5.9 & $3.5,9.8$ & $14 / 18$ & 2.8 & $1.3,6.0$ & $112 / 174$ & 4.0 & $2.7,5.8$ \\
\hline $5-14$ & $80 / 94$ & 8.3 & $4.8,14.2$ & $9 / 13$ & 2.3 & $0.9,5.6$ & $89 / 107$ & 5.3 & $3.5,7.9$ \\
\hline \multicolumn{10}{|l|}{ Passive smoking at home } \\
\hline No & $232 / 521$ & I & & $81 / 260$ & I & & $3|3 / 78|$ & I & \\
\hline Yes & $26 / 32$ & 1.8 & I.I, 3.2 & $46 / 85$ & 1.7 & I.I, 2.8 & $72 / 117$ & 1.8 & $1.3,2.6$ \\
\hline
\end{tabular}

ages 50 years and older. A similar trend is also observed in Table III for the years since quitting smoking; the longer the time since quitting the lower the odds of developing lung cancer. For persons who had quit smoking 15 or more years earlier the reduction in the risk of developing lung cancer is $59 \%$ for both genders, $61 \%$ for males and $56 \%$ for females.
Finally, Table IV presents the independent effect of ever smoking and being passively exposed to smoking at home on the risk of developing lung cancer while adjusting for educational level and the frequency matching variables. The odds ratios for these two variables, in each gender and also in both genders combined, are essentially not affected by the simultaneous 


\section{TABLE III}

\section{Percent reduction (PR) in the Risk of lung Cancer that a never Quitter would have achieved} by changing his/her smoking habit in MeXico City

\begin{tabular}{|c|c|c|c|c|c|c|c|c|c|}
\hline $\begin{array}{l}\text { Change in } \\
\text { smoking habit }\end{array}$ & & lales & & & emales & & Both & $h$ gende & \\
\hline & Cases/Controls & $P R$ & $95 \% \mathrm{Cl}$ & Cases/Controls & $P R$ & $95 \% \mathrm{Cl}$ & Cases/Controls & Is $\quad P R$ & $95 \% \mathrm{Cl}$ \\
\hline Age quitting smoki & & & & & & & & & \\
\hline Never quitter & $137 / 175$ & 0 & & $33 / 36$ & 0 & & $|70 / 2| \mid$ & 0 & \\
\hline $50-85$ & $66 / 97$ & 21.3 & $-19.3,48$ & $15 / 18$ & 17.5 & $-97.8,65.6$ & $81 / 115$ & 20.1 & $-15.9,44.9$ \\
\hline $35-49$ & $24 / 49$ & 40.3 & $-3.7,65.6$ & $5 / 13$ & 62.6 & $-19.7,88.3$ & $29 / 62$ & 44.9 & $9.4,66.5$ \\
\hline $12-34$ & $9 / 35$ & 67.6 & $29.3,85.2$ & $2 / 4$ & 57.2 & $-157.6,92.9$ & $11 / 39$ & 64.3 & $27.2,82.5$ \\
\hline Never smoker & $22 / 197$ & 87.1 & $78.5,92.2$ & $72 / 274$ & 71.3 & $48.8,83.9$ & $94 / 47 \mid$ & 79.5 & $71.1,85.5$ \\
\hline Years since quittin & & & & & & & & & \\
\hline Never quitter & $137 / 175$ & 0 & & $33 / 36$ & 0 & & $|70 / 2| \mid$ & 0 & \\
\hline $2-4$ & $19 / 18$ & -23.2 & $-148.9,39$ & $5 / 5$ & -10.5 & $-338,72.1$ & $24 / 23$ & -20.0 & $-123.8,35.7$ \\
\hline $5-14$ & $40 / 49$ & 3.5 & $-57.9,41.1$ & $9 / 13$ & 35.5 & $-77.9,76.6$ & $49 / 62$ & 9.3 & $-4 I . I, 4 I .7$ \\
\hline $15-63$ & $40 / 1 / 4$ & 61.0 & $38.6,75.2$ & $8 / 17$ & 56.1 & $-18.9,83.8$ & $48 /|3|$ & 59.0 & $38.3,72.7$ \\
\hline Never smoker & $22 / 197$ & 87.1 & $78.5,92.2$ & $72 / 274$ & 71.3 & $48.8,83.9$ & $94 / 47 \mid$ & 79.5 & $7 I . I, 85.5$ \\
\hline
\end{tabular}

\section{TABLE IV}

Multivariate assessment of the efFect of PAssive AND ACtive SMOKING ON LUNG CANCER RISK AND SMOKING POPULATION ATTRIBUTABLE RISKS FOR THE POPULATION AGED 47 YEARS AND OLDER LIVING in Mexico City, ACcording to gender

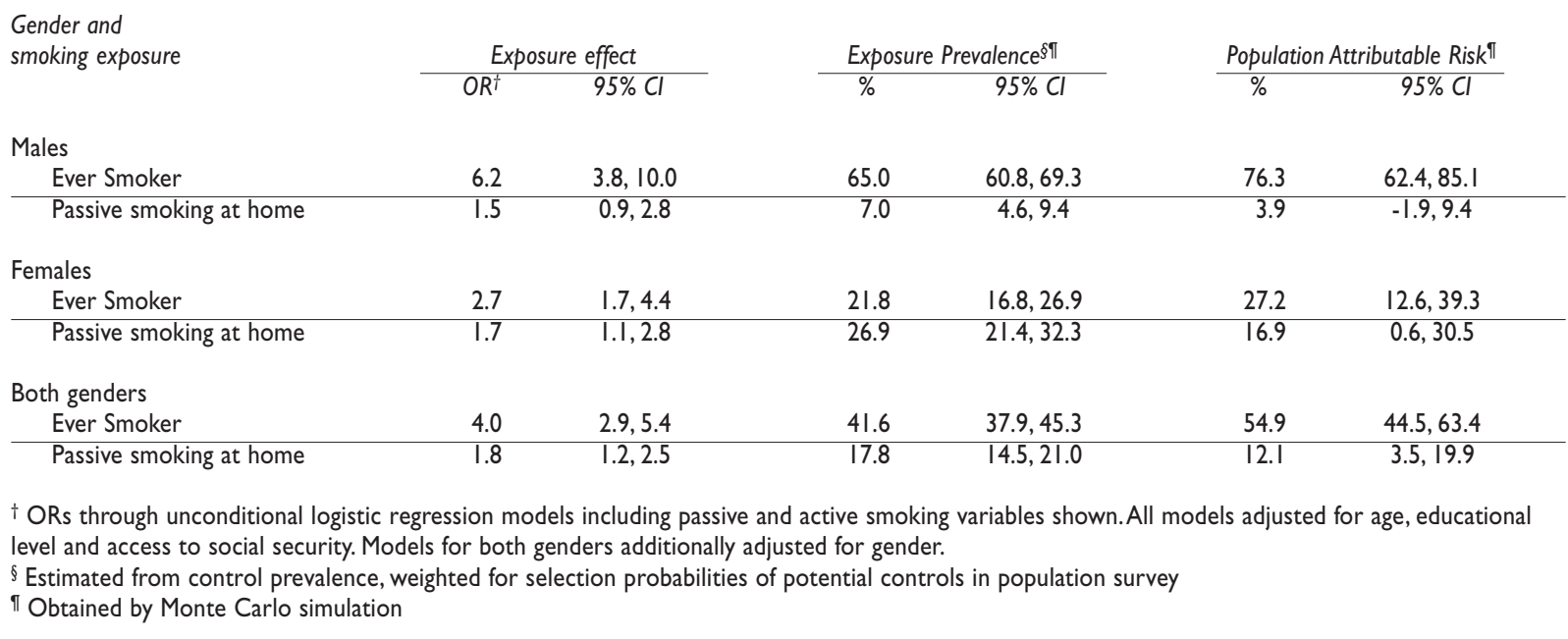

adjustment for each other (compare to the corresponding odds ratios shown in Table II). Also shown in Table IV is the estimated prevalence of ever smoking and passive smoking for the greater Mexico City area population aged 47 years and older. In this population, $65 \%$ of males are ever smokers, whereas the corresponding percentage for females is roughly one third of that observed in males. However, the prevalence of passive smoking in females is $27 \%$, almost four times greater than the prevalence estimated for males. Overall, $55 \%$ of lung cancer cases arising in Mexico City are attributable to active current or past smoking and 12\% to passive smoking at home. The fraction of cases attributable to active smoking is larger for males than 
for females ( $76 \%$ vs. $27 \%$ ). The opposite is true for passive smoking, which is responsible for $17 \%$ of lung cancer cases arising in female residents of Mexico City, whereas in males, passive smoking is responsible for less than $5 \%$ of lung cancer cases (a figure not adequately estimated by our sample size).

\section{Discussion}

The association between both active and passive smoking and lung cancer in Mexico City residents has been presented according to the preliminary analysis of the population-based case-control study. Several features of the study's design and implementation must be evaluated in order to adequately interpret the results.

The first topic has to do with how representative the cases are of those cases arising in Mexico City. All of the tertiary care public hospitals existing in the city were included. Because of the expensive treatment for this disease, it is believed that a small proportion of lung cancer cases are seen in private hospitals. Alternatively, the possibility exists that a significant proportion of lung cancer patients are never seen at tertiary care hospitals. This is suggested by the fact that approximately 1400 lung cancer cases was expected to be ascertained from official mortality data, yet it was possible to detect only 990 probable cases. However, it is difficult to believe that lung cancer cases seen at tertiary care centers in Mexico City are selected on the basis of smoking exposure variables, and therefore, it is contended that the cases in this study approximately represent the smoking exposures existing in all cases arising in the city. Of course, we did not analyze all the lung cancer cases interviewed in the study as medical chart review and diagnostic confirmation is still ongoing. Nevertheless, it is believed that the analyzed cases represent the entire case series of this study with regard to the exposures evaluated, since cases included in this report were not selected on the basis of smoking exposure variables and come from all the hospitals participating in the study.

In addition, our controls were selected from a random sample of greater Mexico City area residents. In order to increase the comparability of cases and controls and in the absence of reliable case data, an imperfect frequency matching on age, gender and access to social security was performed, since it was based on probable rather than confirmed lung cancer cases. Nonetheless, the matching variables were always included in the estimation of odds ratios relating smoking exposures and lung cancer. Estimates of the prevalence of the smoking variables in the city were also corrected considering the selection probabilities of the controls.
Exposure misclassification of smoking variables was attenuated by several strategies. First, the two interviewers were trained to correctly administer the questionnaire in the same fashion. Second, the interviewers were assigned in a random fashion and therefore performed a similar number of interviews of cases detected in each hospital and a similar number of interviews in controls. Third, interviewed cases were interviewed during their first visits to the clinic, when the diagnosis of lung cancer had usually not been established. In fact, the relative odds presented in Table IV, when including all probable cases interviewed (990), are attenuated for both ever smoking and passive smoking, indicating that the non lung cancer probable cases interviewed had a lower prevalence of such exposures (data not shown). Disease misclassification would also have a small impact on this study's results since only clinically and histologically confirmed primary lung cancer cases were analyzed.

With regard to the effect of active cigarette smoking, this study finds similar results to other studies conducted in different parts of the world..$^{3-6} \mathrm{In}$ this study an increasing risk in lung cancer has been observed, both in males and females, with regard to age at the start of smoking, number of cigarettes smoked per day, duration of smoking and cumulative dose measured in pack-years. A beneficial effect on lung cancer risk by quitting smoking, particularly before age 35, has also been shown, as well as a substantial reduction in the risk of lung cancer, particularly after 15 years or more, which is consistent with other studies. ${ }^{6-8}$ In addition, this study indicates that ever smoker women show half the odds ratio observed in men. This difference is explainable by differences in smoking intensity between genders in Mexico. Indeed, female lung cancer cases in this study had an average pack-years of 9.3 compared to 28.3 observed in our lung cancer cases. Furthermore, studies conducted in other countries have not found differences in susceptibility to lung cancer between males and females..$^{9,10}$

This study has also shown an inverse relationship between socioeconomic status and lung cancer, contrary to what has been observed in studies from developed countries. ${ }^{11}$ Nevertheless, the findings presented in this paper are supported by the fact that in Mexico the prevalence and intensity of tobacco smoking is higher as income or educational level rises. ${ }^{12,13}$

Regarding passive smoking, this study finds an odds ratio close to two, very similar to that found in other studies conducted in different parts of the world. ${ }^{13-}$ ${ }^{19}$ As in other studies, this study also found a similar effect of passive smoking in males and females.

It has been estimated that in the population aged 47 years and older residing in Mexico City, roughly three in 
every four lung cancer cases occurring in males and one in every four lung cancer cases occurring in females are due to current or former active smoking. This is similar to findings in Japan, but unlike findings from the other countries where greater attributable risks of active smoking on lung cancer have been reported. ${ }^{1,20-22}$ This discrepancy can be explained by differences in smoking intensities between different countries. A reassuring fact in this study is that the proportion of lung cancer cases that would be left over in males and females by eliminating completely active smoking would similar between genders, given that in our country men lung cancer mortality, and probably also incidence, is three times higher in men than in women.

Passive smoking, on the other hand, is responsible for $17 \%$ of lung cancer cases arising in women in Mexico City and possibly less than $5 \%$ of the lung cancer cases arising in men. The fact that this study reports the prevalence of passive smoking in women as close to four times that reported in men suggests that men probably tended to report this exposure less than women.

Nevertheless, this study finds that approximately one third of lung cancer cases arising in Mexico City are not explained by either active or passive smoking and that this percentage is considerably greater in females. Besides smoking, several risk factors associated with lung cancer have been found. In this sense, there seems to be a genetic susceptibility to developing the disease in both smokers and non smokers as recent familiar aggregation studies have shown. ${ }^{23-25} \mathrm{Su}-$ pporting this evidence are several molecular studies that have found polymorphism in several detoxifying or DNA repairing enzymes associated with lung cancer risk. ${ }^{26,27}$ Also, particularly in females, biomass use has been positively associated with lung cancer risk in several epidemiologic studies. ${ }^{28-31}$ Finally, another factor that may be of importance in lung cancer etiology in Mexico is indoor radon exposure, which in recent case control studies has been found to be related to lung cancer. ${ }^{32-34}$ Indeed, the authors of this report have found high radon concentrations in houses in some areas of Mexico City ${ }^{35}$ and plan to evaluate the role of radon exposure in lung cancer etiology in Mexico City in the case-control study.

\section{Acknowledgments}

The authors would like to express their gratitude to the following persons for their effort and commitment during the implementation of the study: Diana Torres (survey field supervisor), Benjamin Camacho and Rocio Hernandez (data entry and cleaning), Patricia Miranda and Victor Corral (interviewers), Ms. Rosa
Serrano (logistics) and the transportation personnel at the National Institute for Respiratory Diseases.

\section{References}

I. Ezzati M, Lopez AD. Estimates of global mortality attributable to smoking in 2000. Lancet 2003 Sep 13;362(9387):847-52.

2. Greenland S. Interval estimation by simulation as an alternative to and extension of confidence intervals. Int J Epidemiol 2004 Dec;33(6): I389-97.

3. Yu SZ, Zhao N. Combined analysis of case-control studies of smoking and lung cancer in China. Lung Cancer 1996 Mar;14 Suppl I:SI6I-70. 4.Agudo A, Ahrens W, Benhamou E, Benhamou S, Boffetta P, Darby SC, et al. Lung cancer and cigarette smoking in women: a multicenter casecontrol study in Europe. Int J Cancer 2000 Dec I;88(5):820-7.

5. Caicoya M, Miron JA. Cáncer de pulmón y tabaco en Asturias : Un estudio de casos y controles. Gac Sanit 2003 May-Jun; I7(3):226-30. 6. Doll R, Peto R, Boreham J, Sutherland I. Mortality in relation to smoking: 50 years' observations on male British doctors. BMJ 2004 Jun 26;328(7455): I507.

7. Peto R, Darby S, Deo H, Silcocks P,Whitley E, Doll R. Smoking, smoking cessation, and lung cancer in the UK since 1950: combination of national statistics with two case-control studies. BMJ 2000 Aug 5;32I (7257):323-9.

8. Crispo A, Brennan P, Jockel KH, Schaffrath-Rosario A, Wichmann HE, Nyberg F, et al. The cumulative risk of lung cancer among current, exand never-smokers in European men. $\mathrm{Br}$ J Cancer $2004 \mathrm{Oct}$ 4;9|(7): I280-6.

9.Axelsson G, Rylander R. Diet as risk for lung cancer: a Swedish casecontrol study. Nutr Cancer 2002;44(2): |45-5I.

10. Bain C, Feskanich D, Speizer FE, Thun M, Hertzmark E, Rosner BA, Colditz GA. Lung cancer rates in men and women with comparable histories of smoking. J Natl Cancer Inst 2004 Jun 2;96(I I):826-34. I I. Mao Y, Hu J, Ugnat AM, Semenciw R, Fincham S. Socioeconomic status and lung cancer risk in Canada. Int J Epidemiol 2001 Aug;30(4):809-17.

12. Sesma-Vazquez S, Campuzano-Rincon JC, Carreon-Rodriguez VG, Knaul F, Lopez-Antunano FJ, Hernandez-Avila M. El comportamiento de la demanda de tabaco en México: 1992-1998. Salud Publica Mex 2002;44 Suppl I:S82-92.

13.Vazquez-Segovia LA, Sesma-Vazquez S, Hernandez-Avila M. El consumo de tabaco en los hogares en México. Resultados de la Encuesta de Ingresos y Gastos en los hogares, 1984-2000. Salud Publica Mex 2002;44 Suppl I:S76-8I.

14. Kleinerman R, Wang Z, Lubin J, Zhang S, Metayer C, Brenner A. Lung cancer and indoor air pollution in rural China. Ann Epidemiol 2000 Oct I; $10(7): 469$.

15. Johnson KC, Hu J, Mao Y. Lifetime residential and workplace exposure to environmental tobacco smoke and lung cancer in neversmoking women, Canada 1994-97. Int J Cancer 200I Sep;93(6):902-6. 16. Boffetta P. Involuntary smoking and lung cancer. Scand J Work Environ Health 2002;28 Suppl 2:30-40.

17. Kreuzer M, Heinrich J, Kreienbrock L, Rosario AS, Gerken M, Wichmann HE. Risk factors for lung cancer among nonsmoking women. Int J Cancer 2002 Aug 20;100(6):706-13.

18. Brennan P, Buffler PA, Reynolds P,Wu AH,Wichmann HE, Agudo A, Pershagen G, Jockel KH, Benhamou S, Greenberg RS, Merletti F, Winck C, Fontham ET, Kreuzer M, Darby SC, Forastiere F, Simonato L, Boffetta P. Secondhand smoke exposure in adulthood and risk of lung cancer among never smokers: a pooled analysis of two large studies. Int J Cancer 2004 Mar; 109(I): 125-3I. 
19. Behera D, Balamugesh T. Indoor air pollution as a risk factor for lung cancer in women. J Assoc Physicians India 2005 Mar;53:190-2.

20. Menezes AM, Horta BL, Oliveira AL, Kaufmann RA, Duquia R, Diniz

A, Motta LH, Centeno MS, Estanislau G, Gomes L. Risco de câncer de pulmão, laringe e esôfago atribuível ao fumo. Rev Saude Publica 2002 Apr;36(2):129-34.

21. Sitas F, Urban M, Bradshaw D, Kielkowski D, Bah S, Peto R. Tobacco attributable deaths in South Africa. Tob Control 2004 Dec;13(4):396-9. 22. Wakai K, Ando M, Ozasa K, Ito Y, Suzuki K, NishinoY, Kuriyama S, Seki N, Kondo T, Watanabe Y, Ohno Y, Tamakoshi A. Updated information on risk factors for lung cancer: findings from the JACC Study.J Epidemiol 2005 Jun; I5 Suppl 2:SI34-9.

23. Jin YT, Xu YC, Yang RD, Huang CF, Xu CW, He XZ. Familial aggregation of lung cancer in a high incidence area in $\mathrm{China} . \mathrm{Br} J$ Cancer 2005 Apr I I;92(7): I32 I-5.

24. Etzel CJ,Amos Cl, Spitz MR. Risk for smoking-related cancer among relatives of lung cancer patients. Cancer Res. 2003 Dec I;63(23):853I-5. 25. Bromen K, Pohlabeln H, Jahn I, Ahrens W, Jockel KH.Aggregation of lung cancer in families: results from a population-based case-control study in Germany. Am J Epidemiol 2000 Sep 15; I52(6):497-505. 26. Miller DP, De Vivo I, Neuberg D, Wain JC, Lynch TJ, Su L, Christiani DC. Association between self-reported environmental tobacco smoke exposure and lung cancer: modification by GSTPI polymorphism. Int J Cancer 2003 May 10;104(6):758-63.

27. Paz-Elizur T, Krupsky M, Blumenstein S, Elinger D, Schechtman E, Livneh Z. DNA repair activity for oxidative damage and risk of lung cancer.J Natl Cancer Inst 2003 Sep 3;95(I7): I3 |2-9.
28. Behera D, Balamugesh T. J Assoc Physicians India 2005 Mar;53:190-2. 29. Behera D, Balamugesh T. Indoor air pollution as a risk factor for lung cancer in women. J Assoc Physicians India 2005 Mar;53:190-2.

30. Kleinerman RA, Wang Z, Wang L, Metayer C, Zhang S, Brenner AV, Zhang S, Xia Y, Shang B, Lubin JH. Lung cancer and indoor exposure to coal and biomass in rural China.J Occup Environ Med 2002 Apr;44(4):338-44.

3I. Ko YC, Lee CH, Chen MJ, Huang CC, Chang WY, Lin HJ, Wang HZ, Chang PY. Risk factors for primary lung cancer among non-smoking women in Taiwan. Int J Epidemiol 1997 Feb;26(I):24-3I.

32. Krewski D, Lubin JH, Zielinski JM, Alavanja M, Catalan VS, Field RW, Klotz JB, Letourneau EG, Lynch CF, Lyon JI, Sandler DP, Schoenberg JB, Steck DJ, Stolwijk JA, Weinberg C, Wilcox HB. Residential radon and risk of lung cancer: a combined analysis of 7 North American casecontrol studies. Epidemiology 2005 Mar; 16(2):137-45.

33. Barros-Dios JM, Barreiro MA, Ruano-Ravina A, Figueiras A. Exposure to residential radon and lung cancer in Spain: a population-based casecontrol study. Am J Epidemiol 2002 Sep 15; I56(6):548-55.

34. Field RW.A review of residential radon case-control epidemiologic studies performed in the United States. Rev Environ Health $200 \mathrm{I} \mathrm{Jul-}$ Sep; 16(3):15I-67.

Franco-Marina F,Villalba-Caloca J, Segovia N, Tavera L. Spatial indoor radon distribution in Mexico City. Sci Total Environ 2003 Dec 30;317(I3):91-103 